\title{
EQUATIONS FOR DETERMINING THE GAS AND BRINE VOLUMES IN SEA-ICE SAMPLES
}

\author{
By G. F. N. Cox and W. F. WeEKS \\ (U.S. Army Cold Regions Research and Engineering Laboratory, 72 Lyme Road, Hanover, \\ New Hampshire 03755, U.S.A.)
}

\begin{abstract}
AвStract. Equations are developed that can be used to determine the amount of gas present in sea ice from measurements of the bulk ice density, salinity, and temperature in the temperature range of -2 to $-30^{\circ} \mathrm{C}$. Conversely these relationships can be used to give the density of sea ice as a function of its temperature and salinity, considering both the presence of gas and of solid salts in the ice. Equations are also given that allow the calculation of the gas and brine volumes in the ice at temperatures other than that at which the bulk density was determined.
\end{abstract}

RÉsumé. Equations pour déterminer les volumes de gaz et de saumure dans des échantillons de glace de mer. On a établi des équations utilisables pour déterminer le taux de gaz inclus dans la glace de mer à partir de mesures de densité, de salinité et de température dans les gammes de températures entre $-2{ }^{\circ} \mathrm{C}$ et $-30^{\circ} \mathrm{C}$. Inversement ces relations peuvent être utilisées pour calculer la densité de la glace de mer en fonction de la température et de la salinité, en prenant en compte à la fois la présence de gaz et de cristaux de sel dans la glace. On donne aussi des équations qui permettent le calcul du volume de gaz et d'eau salée dans la glace à des températures autres que celle pour laquelle la densité a été dèterminée.

Zusammenfassung. Gleichungen zur Bestimmung des Gas- und Sole-Volumens in Meereisproben. Es werden Gleichungen aufgestellt, die zur Bestimmung der Gasmenge in Meereis aus Messungen der mittleren Eisdichte, des Salzgehaltes und der Temperatur im Bereich von -2 bis $-30^{\circ} \mathrm{C}$ herangezogen werden können. Umgekehrt lassen sich diese Beziehungen zur Bestimmung der Dichte von Meereis in Abhängigkeit von seiner Temperatur und seines Salzgehaltes unter Annahme des Vorhandenseins von Gas und festen Salzen im Eis benutzen. Weitere Gleichungen erlauben die Berechnung des Gas- und Sole-Volumens im Eis bei Temperaturen, die von jenen absweichen, bei denen die mittlere Dichte bestimmt wurde.

\section{INTRODUCTION}

A knowledge of the total porosity of sea ice is important in interpreting its physical properties. It has been shown, both theoretically and experimentally, that the mechanical, thermal, and electrical properties of sea ice vary with the relative volume of brine existing in the ice (Weeks and Assur, 1967; Schwarz and Weeks, 1977). However, the air or gas volume in the ice is also important. This is particularly true for low-salinity sea ice, such as multi-year ice, where the gas volume may make up a major portion of its total porosity.

The gas volume of sea ice can be calculated given the density, salinity, and temperature of the ice. Generally, Assur's (1958) phase equilibrium table (table III, p. 124) is used to perform such calculations. This table gives the relative masses of the different components in "standard sea ice" at temperature intervals of $2 \mathrm{deg}$. These data are based primarily on the experimental determinations of Nelson and Thompson (1954) and Ringer (1928). Here the expression standard sea ice is used to refer to sea ice of such a composition that the relative concentrations of ions in its melt water are the same as in normal sea-water. From the density of the various components, the theoretical, or gas-free, density of the sea ice can then be calculated and compared to the measured density to determine the actual gas volume present in the ice. However, since the table is based on standard sea ice having a salinity of $34.325 \%$, it is first 
necessary to reduce the data to the appropriate ice salinity. This is done by multiplying the masses of all the components, except pure ice, by $S_{\mathrm{i}} / 34.325$ where $S_{\mathrm{i}}$ is the ice salinity in parts per thousand. The mass of pure ice is then $1.000 \mathrm{~g}$ minus the total mass of brine and precipitated salts. Even though these calculations are straight-forward, they are both time-consuming and prone to arithmetic errors. In fact they are rarely performed and estimates of the amount of gas present in sea ice and of the total void volume of the ice are rarely obtained.

In the present paper, equations are derived from which the gas volume and brine volume can be directly calculated given the ice salinity, temperature, and density. The equations cover the temperature range from $-2{ }^{\circ} \mathrm{C}$ to $-30^{\circ} \mathrm{C}$ and consider the presence of solid salts. Equations are also given to calculate sea-ice density and the variation of gas and brine volume of a sea-ice sample, if the temperature of the sample is changed from the temperature at which the ice density was originally obtained.

\section{PREVIOUS WORK}

Only a few investigators have advanced methods for calculating the density and gas volume in sea ice. Zubov (1945) calculated the density of gas-free sea ice and provided a table of values that could be used at temperatures of $-23{ }^{\circ} \mathrm{C}$ and warmer. However, his work was done prior to Nelson and Thompson's (1954) experiments on the chemistry of sea-ice brine. Zubov also did not take into account the presence of solid salts. In 1960, Anderson (1960) published a table giving the density of gas-free sea ice at 14 selected temperatures in the temperature range between 0 and $-50^{\circ} \mathrm{C}$. This work was based on Assur's (1958) phase relations. As the exact method of calculation is not given, it is not clear whether Anderson considered the presence of solid salts in the ice. The only relation available that calculates the gas volume of sea ice directly was developed by Schwerdtfeger (1963). However, it is only valid at temperatures warmer than $-8.2{ }^{\circ} \mathrm{C}$, the $\mathrm{Na}_{2} \mathrm{SO}_{4} \cdot 10 \mathrm{H}_{2} \mathrm{O}$ crystallization temperature. He also neglected the presence of solid salts and assumed that the volume of brine was equal to that of pure water. For warm sea ice these are reasonable approximations. At the conclusion of this report comparisons are made between the results of these previous authors and the present results.

It should also be noted here that Assur's (1958) brine volume table and the brine volume equations based on this table derived by Frankenstein and Garner (1967) assume a constant ice density of $0.926 \mathrm{Mg} / \mathrm{m}^{3}$. Consequently, these reports should be used with caution in gas volume calculations. The brine volume obtained from these sources should be multiplied by $\rho / 0.926$. where $\rho$ is the gas-free theoretical density, or better still, the measured ice density in $\mathrm{Mg} / \mathrm{m}^{3}$ at the temperature of interest, to determine the brine volume for a given sea ice density.

\section{DERIVATION OF EQUATIONS}

A sample of sea ice is composed of pure ice, brine, solid salts, and gas. In determining the gas volume of sea ice we are interested in the relative masses and volumes of the different components at a given ice salinity, temperature, and bulk density.

In the derivations to follow, $m_{l}, \rho_{l}$, and $V_{l}$ are the mass, density, and volume of component $l$ where the subscripts a, b, i, s, and ss denote the component air, brine, pure ice, salt, and solid salts, respectively. $M$ is the bulk mass, $V$ the bulk volume, and $\rho$ the bulk density (these should not be confused with the gas-free theoretical mass, volume, and density). The terms $m_{\mathrm{s}}^{\mathrm{b}}$ and $m_{\mathrm{s}}^{\mathrm{ss}}$ 
denote the mass of salt in the brine and mass of salt in the solid salts, respectively. The mass of gas in the ice is assumed to be negligible.

\section{Brine volume}

The salinity of the ice $S_{\mathrm{i}}$ is defined as

$$
S_{\mathrm{i}}=\frac{m_{\mathrm{s}}}{M}=\frac{m_{\mathrm{s}}^{\mathrm{b}}+m_{\mathrm{s}}^{\mathrm{ss}}}{m_{\mathrm{b}}+m_{\mathrm{ss}}+m_{\mathrm{i}}} .
$$

The salinity of the brine $S_{\mathrm{b}}$ is defined as

$$
S_{\mathrm{b}}=\frac{m_{\mathrm{s}}^{\mathrm{b}}}{m_{\mathrm{b}}} .
$$

From these two relations an equation for the brine volume of sea ice can be derived. It should be noted that the brine salinity and the relative amounts of salt in the brine and solid salts are unique functions of ice temperature via phase relations.

From Equation (1):

$$
M S_{\mathrm{i}}=m_{\mathrm{s}}^{\mathrm{ss}}+m_{\mathrm{s}}^{\mathrm{b}}
$$

and

$$
m_{\mathrm{s}}^{\mathrm{b}}=M S_{\mathrm{i}}-m_{\mathrm{s}}^{\mathrm{ss}}
$$

or

$$
m_{\mathrm{s}}^{\mathrm{b}}=M S_{\mathrm{i}}-k m_{\mathrm{s}}^{\mathrm{b}}
$$

where

$$
k=\frac{m_{\mathrm{s}}^{\mathrm{ss}}}{m_{\mathrm{s}}^{\mathrm{b}}} .
$$

Solving for $m_{\mathrm{s}}^{\mathrm{b}}$ from Equation (3) and noting from Equation (2) that

$$
m_{\mathrm{s}}^{\mathrm{b}}=\rho_{\mathrm{b}} V_{\mathrm{b}} S_{\mathrm{b}},
$$

we obtain

$$
V_{\mathrm{b}}=\frac{M S_{\mathrm{i}}}{\rho_{\mathrm{b}} S_{\mathrm{b}}}\left(\frac{1}{1+k}\right)
$$

which, because $M=\rho V$, can also be written as

$$
\frac{V_{\mathrm{b}}}{V}=\frac{\rho S_{\mathrm{i}}}{\rho_{\mathrm{b}} S_{\mathrm{b}}}\left(\frac{1}{1+k}\right)
$$

where $V_{\mathrm{b}} / V$ is the relative brine volume. If we neglect the salt present as solid salt, $k=0$, and Equation 4 reduces to

$$
\frac{V_{\mathrm{b}}}{V}=\frac{\rho S_{\mathrm{i}}}{\rho_{\mathrm{b}} S_{\mathrm{b}}},
$$

a relation utilized earlier by Weeks and Lofgren (1967). 
Because the brine density can be approximated (Zubov, 1945; Cox and Weeks, 1975) by

$$
\rho_{\mathrm{b}}\left(\mathrm{Mg} / \mathrm{m}^{3}\right)=1+0.0008 S_{\mathrm{b}}(\%)
$$

and because $S_{\mathrm{b}}$ and $k$ are unique functions of temperature, the relative brine volume can be expressed as

$$
\frac{V_{\mathrm{b}}}{V}=\frac{\rho S_{\mathrm{i}}}{F_{1}(T)}
$$

where $S_{\mathrm{i}}$ is in parts per thousand, $\rho$ is in $\mathrm{Mg} / \mathrm{m}^{3}$, and

$$
F_{1}(T)=\rho_{\mathrm{b}} S_{\mathrm{b}}(1+k) .
$$

Values for $F_{1}(T)$ are given in Table I and plotted against temperature in Figure 1. $S_{\mathrm{b}}$ and $k$ are determined from Assur's (1958) phase equilibrium table. The lines through the data in Figure 1 are least-squares curves of the form

$$
F_{1}(T)=\alpha_{0}+\alpha_{1} T+\alpha_{2} T^{2}+\alpha_{3} T^{3}
$$

where $T$ is the ice temperature $\left({ }^{\circ} \mathrm{C}\right)$. Coefficients for the curves are given in Table II (p. 312).

\section{Solid salt volume}

Also, via the phase relations, at any given temperature the mass of solid salts (if solid salts are present) is proportional to the mass of brine, that is

$$
m_{\mathrm{ss}}=C m_{\mathrm{b}}
$$

where $C$ is a function of temperature. The relative volume of solid salts $V_{\text {ss }} / V$ is then equal to

$$
\frac{V_{\mathrm{ss}}}{V}=C \frac{\rho_{\mathrm{b}}}{\rho_{\mathrm{ss}}} \frac{V_{\mathrm{b}}}{V}
$$

where $\rho_{\text {ss }}$ is the average solid salt density assumed to be constant at $1.5 \mathrm{Mg} / \mathrm{m}^{3}$.

TABLE I. VALUES FOR $S_{\mathrm{b}}, k, C, F_{1}(T)$, AND $F_{2}(T)$ AT DIFFERENT

TEMPERATURES

\begin{tabular}{cccrrr}
$T$ & \multicolumn{1}{c}{$S_{\mathrm{b}}$} & \multicolumn{1}{c}{$F_{1}(T)$} & \\
${ }^{\circ} \mathrm{C}$ & $\begin{array}{c}\% \\
\text { oo }\end{array}$ & \multicolumn{1}{c}{$10^{-3} k$} & $10^{-3} \mathrm{C}$ & \multicolumn{1}{c}{$\mathrm{Mg} / \mathrm{m}^{3}$} & $F_{2}(T)$ \\
-2 & 37.6 & 0 & 0 & 38.731 & 0.123 \\
-4 & 70.6 & 0.554 & 0.148 & 74.662 & 0.151 \\
-6 & 99.8 & 1.050 & 0.387 & 107.876 & 0.177 \\
-8 & 126.5 & 1.400 & 0.660 & 139.441 & 0.199 \\
-10 & 142.8 & 55.277 & 18.256 & 167.865 & 0.222 \\
-12 & 157.6 & 84.141 & 30.493 & 192.378 & 0.240 \\
-14 & 171.5 & 97.627 & 38.421 & 214.143 & 0.256 \\
-16 & 184.4 & 106.330 & 44.952 & 234.033 & 0.271 \\
-18 & 197.0 & 112.570 & 50.808 & 253.588 & 0.284 \\
-20 & 209.9 & 118.078 & 56.851 & 274.074 & 0.298 \\
-22 & 222.6 & 123.090 & 63.015 & 294.496 & 0.312 \\
-24 & 230.5 & 509.787 & 217.168 & 412.236 & 0.394 \\
-26 & 232.7 & 1312.694 & 537.697 & 638.433 & 0.556 \\
-28 & 234.1 & 2065.827 & 842.341 & 852.171 & 0.708 \\
-30 & 235.6 & 2685.708 & 1098.887 & 1032.102 & 0.836
\end{tabular}




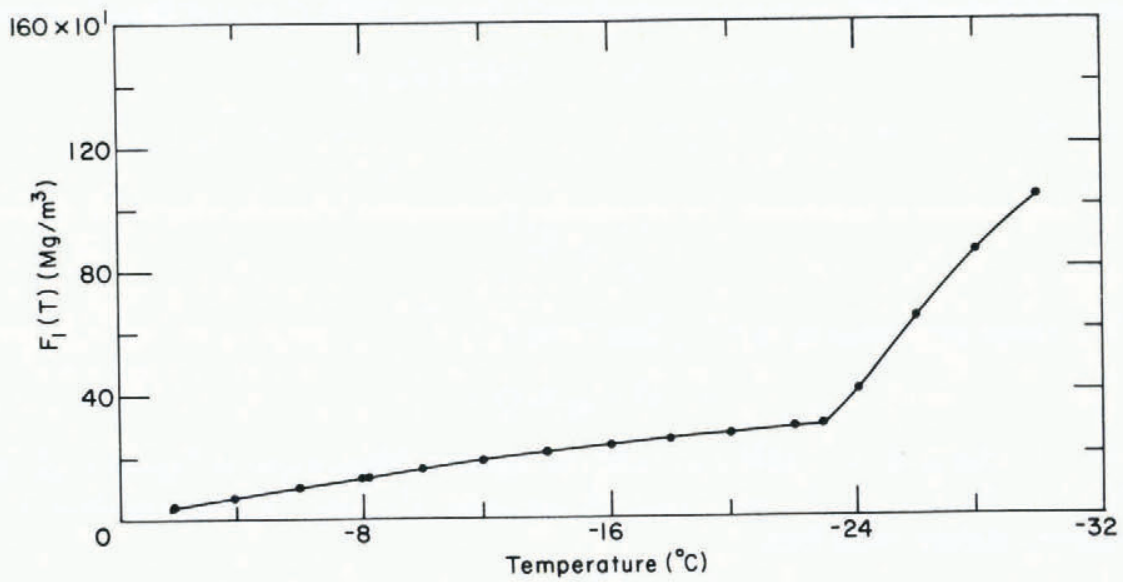

Fig. 1. Function $F_{1}(T)$ versus temperature. Curves determined by method of least squares.

\section{Pure ice volume}

The mass of pure ice is equal to

$$
m_{\mathrm{i}}=M-m_{\mathrm{b}}-m_{\mathrm{ss}}
$$

or from Equation 8

$$
m_{\mathrm{i}}=M-(1+C) m_{\mathrm{b}}
$$

Since

$$
\begin{gathered}
m_{\mathrm{i}}=\rho_{\mathrm{i}} V_{\mathrm{i}} \\
M=\rho V \\
m_{\mathrm{b}}=\rho_{\mathrm{b}} V_{\mathrm{b}}
\end{gathered}
$$

we have

$$
\rho_{\mathrm{i}} V_{\mathrm{i}}=\rho V-(1+C) \rho_{\mathrm{b}} V_{\mathrm{b}} .
$$

Solving for the relative pure ice volume $V_{\mathrm{i}} / V$ we obtain:

$$
\frac{V_{\mathrm{i}}}{V}=\frac{\rho}{\rho_{\mathrm{i}}}-(1+C) \frac{\rho_{\mathrm{b}}}{\rho_{\mathrm{i}}} \frac{V_{\mathrm{b}}}{V} .
$$

\section{Air volume}

The relative air volume $V_{\mathrm{a}} / V$ is equal to

$$
\frac{V_{\mathrm{a}}}{V}=1-\frac{V_{\mathrm{b}}}{V}-\frac{V_{\mathrm{i}}}{V}-\frac{V_{\mathrm{ss}}}{V} .
$$


Substituting Equations (9) and (10) into (11) we obtain

$$
\frac{V_{\mathrm{a}}}{V}=1-\frac{\rho}{\rho_{\mathrm{i}}}+\frac{V_{\mathrm{b}}}{V}\left\{(1+C) \frac{\rho_{\mathrm{b}}}{\rho_{\mathrm{i}}}-C \frac{\rho_{\mathrm{b}}}{\rho_{\mathrm{ss}}}-1\right\} .
$$

Equation (12) can be simplified by defining

$$
F_{2}(T) \equiv\left\{(1+C) \frac{\rho_{\mathrm{b}}}{\rho_{\mathrm{i}}}-\frac{C \rho_{\mathrm{b}}}{\rho_{\mathrm{ss}}}-1\right\},
$$

substituting for $\left(V_{\mathrm{b}} / V\right)$ from Equation (4), and recalling the definition of $F_{1}(T)$ given in Equation (6). The resulting relation is

$$
\frac{V_{\mathrm{a}}}{V}=1-\frac{\rho}{\rho_{\mathrm{i}}}+\rho S_{\mathrm{i}} \frac{F_{2}(T)}{F_{1}(T)} .
$$

Values for $F_{2}(T)$ are given in Table I and plotted against temperature in Figure 2. $C$ is determined from Assur's (1958) phase equilibrium table. The lines through the data in Figure 2 are also least-squares curves of the same form as Equation (7).

Coefficients for these curves are given in Table II. In determining the value of $F_{2}(T)$ at a given temperature, the pure ice density was calculated from (Pounder, 1965);

$$
\rho_{\mathrm{i}}\left(\mathrm{Mg} / \mathrm{m}^{3}\right)=0.917-1.403 \times 10^{-4} T\left({ }^{\circ} \mathrm{C}\right) .
$$

\section{Sea-ice density}

The sea-ice density can be found from Equation (14) by solving for $\rho$ :

$$
\rho=\left(1-\frac{V_{\mathrm{a}}}{V}\right) \frac{\rho_{\mathrm{i}} F_{1}(T)}{F_{1}(T)-\rho_{\mathrm{i}} S_{\mathrm{i}} F_{2}(T)} .
$$

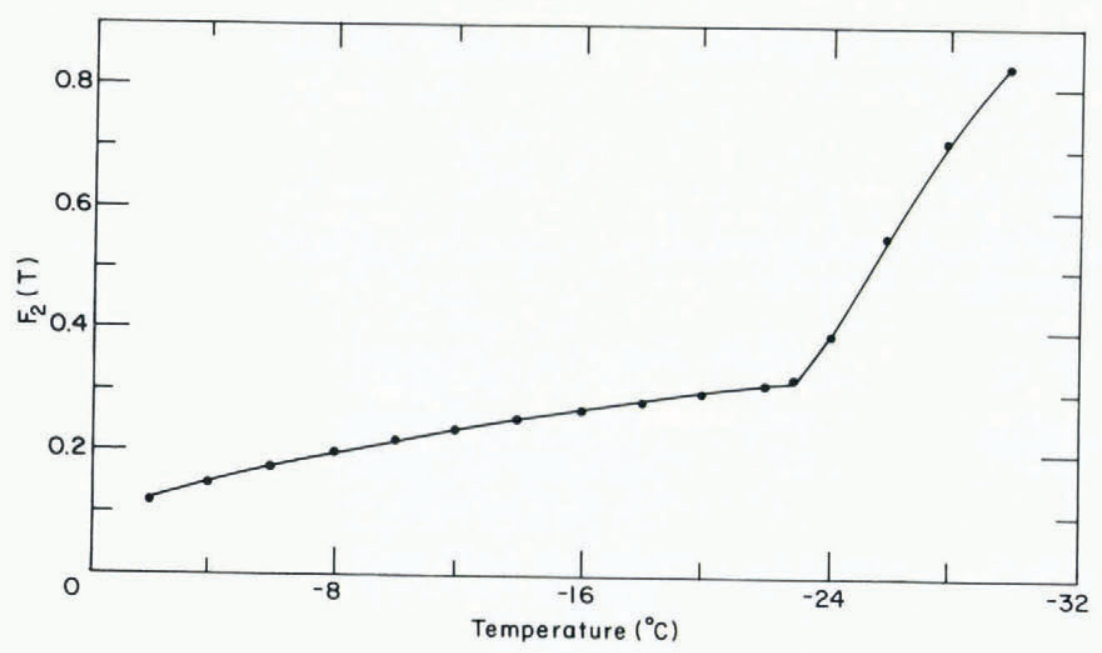

Fig. 2. Function $F_{2}(T)$ versus temperature. Curves determined by method of least squares. 
TABLE II. COEFFICIENTS FOR FUNCTIONS $F_{1}(T)$ AND $F_{2}(T)$ DETERMINED BY METHOD OF LEAST-SQUARES

\begin{tabular}{|c|c|c|c|c|c|}
\hline \multirow[t]{2}{*}{$\begin{array}{c}T \\
{ }^{\circ} \mathrm{C}\end{array}$} & \multicolumn{4}{|c|}{$\begin{array}{c}F_{1}(T) \\
\mathrm{Mg} / \mathrm{m}^{3}\end{array}$} & \multirow[t]{2}{*}{$\begin{array}{c}\text { Correlation } \\
\text { coefficient }\end{array}$} \\
\hline & $\alpha_{0}$ & $\alpha_{1}$ & $\alpha_{2}$ & $\alpha_{3}$ & \\
\hline $\begin{array}{l}-2 \geqslant T \geqslant-22.9 \\
-22.9>T \geqslant-30\end{array}$ & $\begin{array}{r}-4.732 \\
9.899 \times 10^{3}\end{array}$ & $\begin{array}{r}-2.245 \times 10^{1} \\
1.309 \times 10^{3}\end{array}$ & $\begin{array}{c}-6.397 \times 10^{-1} \\
5.527 \times 10^{1}\end{array}$ & $\begin{array}{r}-1.074 \times 10^{-2} \\
7.160 \times 10^{-1}\end{array}$ & $\begin{array}{l}0.9999 \\
0.9999\end{array}$ \\
\hline \multicolumn{6}{|c|}{$F_{2}(T)$} \\
\hline $\begin{array}{l}-2 \geqslant T \geqslant-22.9 \\
-22.9>T \geqslant-30\end{array}$ & $\begin{array}{l}8.903 \times 10^{-2} \\
8.547\end{array}$ & $\begin{array}{l}-1.763 \times 10^{-2} \\
1.089\end{array}$ & $\begin{array}{r}-5.330 \times 10^{-4} \\
4.518 \times 10^{-2}\end{array}$ & $\begin{array}{r}-8.801 \times 10^{-6} \\
5.819 \times 10^{-4}\end{array}$ & $\begin{array}{l}0.9999 \\
0.9999\end{array}$ \\
\hline
\end{tabular}

Unlike the calculated densities given in Schwerdtfeger (1963) and Anderson (1960), this equation considers the presence of both air and solid salts in the ice. A comparison between the different density estimates is given later in this paper.

\section{Gas volume at another temperature}

The gas volume and brine volume of sea ice are determined by measuring the volume and mass of the ice sample at a given temperature and the salinity of the melted sample. If tests are conducted at a temperature different from the temperature at which the bulk density was determined, the air and brine volume must be recalculated.

Equations are now derived to calculate the air and brine volumes at a temperature that differs from the temperature at which the ice density was determined. Primed variables denote the initial value of the different variables.

It is initially assumed that the brine and air pockets are inter-connected. From Equation (5) we know that

$$
V_{\mathrm{b}}=\frac{M S_{\mathrm{i}}}{F_{1}(T)} .
$$

Because the mass and bulk salinity of the ice do not change with temperature,

$$
V_{\mathrm{b}}=V_{\mathrm{b}}^{\prime} \frac{F_{1}^{\prime}(T)}{F_{1}(T)} .
$$

By re-arranging Equation (14), substituting for $\rho$ based on Equation (5), and defining

$$
F_{3}\left(S_{\mathrm{i}}, T\right) \equiv \frac{\rho_{\mathrm{i}} S_{\mathrm{i}}}{F_{1}(T)-\rho_{\mathrm{i}} S_{\mathrm{i}} F_{2}(T)}
$$

it can be shown that

$$
V_{\mathrm{b}}=\left(V-V_{\mathrm{a}}\right) F_{3}\left(S_{\mathrm{i}}, T\right) .
$$

Also dividing both sides of Equation (16) by $V$ and noting that

$$
V=\frac{\rho^{\prime} V^{\prime}}{\rho}
$$


we obtain for the new relative brine volume

$$
\frac{V_{\mathrm{b}}}{V}=\frac{\rho}{\rho^{\prime}} \frac{V_{\mathrm{b}}^{\prime}}{V^{\prime}} \frac{F_{1}^{\prime}(T)}{F_{1}(T)} .
$$

From Equation (18) we can also conclude that

$$
\frac{V_{\mathrm{b}}}{V_{\mathrm{b}}^{\prime}}=\frac{\left(V-V_{\mathrm{a}}\right) F_{3}\left(S_{\mathrm{i}}, T\right)}{\left(V^{\prime}-V_{\mathrm{a}}^{\prime}\right) F_{3}^{\prime}\left(S_{\mathrm{i}}, T\right)} .
$$

Substituting Equation (19) into Equation (20) and solving for $V_{\mathrm{a}} / V$ we obtain for the new relative air volume

$$
\frac{V_{\mathrm{a}}}{V}=1-\left(1-\frac{V_{\mathrm{a}}^{\prime}}{V^{\prime}}\right)\left(\frac{\rho}{\rho^{\prime}}\right)\left(\frac{F_{3}^{\prime}\left(S_{\mathrm{i}}, T\right) F_{\mathrm{i}}^{\prime}(T)}{F_{3}\left(S_{\mathrm{i}}, T\right) F_{1}(T)}\right) .
$$

If the volume of the sample is not known at the new temperature, one can assume that the change in the external dimensions of the sample is due to the volumetric change in the ice matrix, that is

$$
\frac{\rho}{\rho^{\prime}} \approx \frac{\rho_{\mathrm{i}}}{\rho_{\mathrm{i}}^{\prime}} .
$$

In the temperature range where many investigations are carried out

$$
\frac{\rho_{\mathrm{i}}}{\rho_{\mathrm{i}}^{\prime}} \approx 1 .
$$

If the brine and gas pockets are not connected, a change in gas volume may also take place if the ice is warmed, that is, as less dense ice is melted to dilute the brine. In this case, the relative volume of the gas pockets remains the same, but voids are produced in the brine cavities. By setting $V_{\mathrm{a}}^{\prime} / V^{\prime}$ to zero in Equation (21) we can estimate the increase in the relative gas volume in the brine cavities. Adding this to the original relative gas volume, we obtain

$$
\frac{V_{\mathrm{a}}}{V}=\frac{V_{\mathrm{a}}^{\prime}}{V^{\prime}}+1-\frac{\rho}{\rho^{\prime}} \frac{F_{3}^{\prime}\left(S_{\mathrm{i}}, T\right) F_{\mathrm{i}}^{\prime}(T)}{F_{3}\left(S_{\mathrm{i}}, T\right) F_{1}(T)}
$$

and in many applications

$$
\frac{\rho}{\rho^{\prime}} \approx \frac{\rho_{\mathrm{i}}}{\rho_{\mathrm{i}}^{\prime}} \approx 1
$$

If the brine and air pockets are not connected and the ice is cooled, the relative air volume will not change. However, due to phase changes, some brine will be lost from the sample as a result of brine expulsion.

\section{Discussion}

As methods for calculating the gas content of sea ice invariably contain a calculation of the density of gas-free sea ice, it is interesting to compare the density estimates developed in this report with previously published estimates. Table III gives such a comparison. As can be seen, 
Table III. Calculated densities (in $\mathrm{Mg} / \mathrm{m}^{3}$ ) OF GAS-Free SEA iCE AT DIFFERENT TEMPERATURES AND SALINITIES AS GIVEN BY DIFFERENT AUTHORS

$\begin{array}{llcccc}\quad T=-2{ }^{\circ} \mathrm{C} & 1 & 3 & 5 & 10 & 20 \% \\ \text { Zubov }(1945) & 0.922 & 0.926 & 0.930 & 0.939 & \\ \text { Anderson }(1960) & 0.9198 & 0.9252 & 0.9307 & 0.9447 & 0.9739 \\ \text { Schwerdtfeger }(1963) & 0.9191 & 0.9233 & 0.9275 & 0.9379 & 0.9588 \\ \text { This paper } & 0.9200 & 0.9254 & 0.9308 & 0.9448 & 0.9740 \\ \quad T=-8^{\circ} \mathrm{C} & & & & & \\ \quad & 0.920 & 0.923 & 0.925 & 0.932 & 0.944 \\ \text { Zubov }(1945) & 0.9192 & 0.9216 & 0.9240 & 0.9301 & 0.9426 \\ \text { Anderson }(1960) & 0.9175 & 0.9186 & 0.9196 & 0.9222 & 0.9275 \\ \text { Schwerdtfeger }(1963) & 0.9193 & 0.9218 & 0.9242 & 0.9303 & 0.9429 \\ \text { This paper } & & & & & \\ \quad T=-10{ }^{\circ} \mathrm{C} & 0.920 & 0.922 & 0.925 & 0.929 & \\ \quad \text { Zubov }(1945) & 0.9194 & 0.9216 & 0.9239 & 0.9296 & 0.9412 \\ \text { Anderson }(1960) & 0.9195 & 0.9218 & 0.9240 & 0.9297 & 0.9413 \\ \text { This paper } & & & & & \\ \quad T=-30{ }^{\circ} \mathrm{C} & 0.9216 & 0.9230 & 0.9245 & 0.9281 & 0.9354 \\ \quad & 0.9219 & 0.9233 & 0.9247 & 0.9281 & 0.9352\end{array}$

the agreement between the present results and those of Anderson (1960) is very good (the present values are at most $+0.0003 \mathrm{Mg} / \mathrm{m}^{3}$ higher with a modal difference of only $+0.0001 \mathrm{Mg} / \mathrm{m}^{3}$ ). This agreement is, however, not surprising in that both Anderson's and our calculations are based on Assur's phase equilibrium tables. The agreement essentially verifies both sets of calculations. When comparisons are made with Schwedtfeger's (1963) results for sea ice warmer than $-8.2^{\circ} \mathrm{C}$, much larger differences are found. Within this temperature range these differences vary from $+0.0009 \mathrm{Mg} / \mathrm{m}^{3}$ at warm temperatures $\left(-2{ }^{\circ} \mathrm{C}\right)$ and low salinites $(1.0 \%)$ to $+0.0154 \mathrm{Mg} / \mathrm{m}^{3}$ at $-8^{\circ} \mathrm{C}$ and $20 \%$. The agreement with the earlier values of Zubov (1945) is better than with Schwerdtfeger, with the largest difference being $+0.0058 \mathrm{Mg} / \mathrm{m}^{3}$.

It is also interesting to use the relations that have been developed to examine the importance of considering the presence of solid salts in making gas volume calculations. For sea ice warmer than $-8.2^{\circ} \mathrm{C}$, Schwerdtfeger (1963) calculated the relative air volume from

$$
\frac{V_{\mathrm{a}}}{V}=1-\frac{\rho}{1000}\left(\frac{1000-S_{\mathrm{i}}}{0.917}+\frac{4.98 S_{\mathrm{i}}}{T}\right)
$$

where $\rho$ is in $\mathrm{Mg} / \mathrm{m}^{3}, S_{\mathrm{i}}$ in $\%$, and $T$ in ${ }^{\circ} \mathrm{C}$. As mentioned earlier he neglected the presence of solid salts and assumes that the volume of brine in the ice is equal to the volume of pure water. If we neglect the presence of solid salts in our equations, Equation (12) simplifies to

$$
\frac{V_{\mathrm{a}}}{V}=\left(1-\frac{\rho}{\rho_{\mathrm{i}}}\right)+\frac{\rho S_{\mathrm{i}}}{S_{\mathrm{b}}}\left(\frac{1}{\rho_{\mathrm{i}}}-\frac{1}{\rho_{\mathrm{b}}}\right) .
$$

The results from Equations (23) and (24) are compared with the results from Equation (12) in Table IV. The air volume of sea ice of different assumed salinities, densities, and temperatures are calculated using these three equations.

All the calculated values at a given salinity, density, and temperature are in close agreement. This indicates that, even for sea ice below the $\mathrm{NaCl} \cdot 2 \mathrm{H}_{2} \mathrm{O}$ eutectic temperature, neglecting the 
TABle IV. Air volume (\%o) CAlCUlATIONS From THREE METHOdS FOR SEA ICE HAVING DIFFERENT DENSITIES, SALINITIES, AND TEMPERATURES

\begin{tabular}{|c|c|c|c|c|c|c|c|c|c|}
\hline$T$ & & & & & $\begin{array}{c}\rho \\
\mathrm{Mg} / \mathrm{m}^{3}\end{array}$ & & & & \\
\hline${ }^{\circ} \mathrm{C}$ & & 0.890 & & & 0.910 & & & 0.930 & \\
\hline$S_{\mathrm{i}}=1 \%$ & 1 & 2 & 3 & 1 & 2 & 3 & 1 & 2 & 3 \\
\hline-6 & 31.1 & 31.8 & 31.8 & 9.4 & 10.0 & 10.0 & - & - & - \\
\hline-10 & & 32.0 & 32.1 & & 10.2 & 10.4 & - & - & - \\
\hline-20 & & 33.4 & 33.4 & & 11.7 & 11.7 & - & - & - \\
\hline-30 & & 34.8 & 34.6 & & 13.1 & 12.9 & - & 一 & - \\
\hline$T$ & & & & & $\begin{array}{c}\rho \\
\mathrm{Mg} / \mathrm{m}^{3}\end{array}$ & & & & \\
\hline${ }^{\circ} \mathrm{C}$ & & 0.890 & & & 0.910 & & & 0.930 & \\
\hline$S_{\mathrm{i}}=10 \%$ & 1 & 2 & 3 & 1 & 2 & 3 & 1 & 2 & 3 \\
\hline-6 & 46.5 & 44.9 & 44.8 & 25.1 & 23.5 & 23.3 & 3.7 & 2.0 & 1.9 \\
\hline-10 & & 42.7 & 42.7 & & 21.2 & 21.2 & - & - & - \\
\hline-20 & & 42.2 & 42.1 & & 20.7 & 20.6 & - & - & - \\
\hline-30 & & 43.1 & 41.0 & & 21.6 & 19.4 & - & - & - \\
\hline
\end{tabular}

Schwerdtfeger's results are given in column 1, our results (neglecting solid salts) in column 2, and our results (considering solid salts) in column 3.

presence of solid salts in air volume calculations is a reasonable assumption. For warm, high density, high salinity sea ice $\left(0.930 \mathrm{Mg} / \mathrm{m}^{3}\right)$, Schwerdtfeger's value differs by $1.8 \%$, or nearly $100 \%$. However, the brine volume of this ice is relatively much greater $(85.1 \%$ ) and there is little difference in the total ice porosity.

\section{Conclusions}

Equations have been derived to calculate quickly the air volume of sea ice considering the presence and absence of solid salts. The results show that neglecting the presence of solid salts is a reasonable assumption. However, in this era of computers and sophisticated hand calculators, we recommend considering the presence of solid salts and the use of Equation (12) to calculate the air volume of sea ice. A program for making such calculations on a Hewlett-Packard $41 \mathrm{C}$ calculator is available from the authors.

Earlier we mentioned that very few direct determinations of the gas content of sea ice have been undertaken. This might lead the reader to question the usefulness of the calculations outlined here because of a lack of available comparisons between calculated gas porosities and measured gas porosities. Fortunately such a comparison has now been completed for first-year sea ice (Nakawo, 1983) indicating a very good agreement between the calculated and measured gas porosities. Inasmuch as the calculation procedure we have developed is very rapid, and the measurements required to utilize it are simple, it is hoped that gas volume will, in the future, join brine volume and specimen temperature as part of the sample description for all physical property tests on sea ice.

\section{ACKNOWLEDGEMENTS}

This study was sponsored by Shell Development Company and the Minerals Management 
Service of the U.S. Department of the Interior with support from Amoco Production Company, Arco Oil and Gas Company, Chevron Oil Field Research Company, Exxon Production Research Company, Gulf Research and Development Company, Mitsui Engineering and Shipbuilding Company, the National Science Foundation, Sohio Petroleum Company, Texaco, the U.S. Department of Energy, and the U.S. Coast Guard.

MS. received 30 September 1982 and in revised form 15 November 1982

\section{REFERENCES}

Anderson, D. L. 1960. The physical constants of sea ice. Research, Vol. 13, No. 8, p. 310-18.

Assur, A. 1958. Composition of sea ice and its tensile strength. (In Arctic sea ice. Washington, D.C., p. 106-38 (U.S. National Academy of Sciences-National Research Council Publication 598.))

Cox, G. F. N., and Weeks, W. F. 1975. Brine drainage and initial salt entrapment in sodium chloride ice. U.S. Cold Regions Research and Engineering Laboratory. Research Report 345.

Frankenstein. G., and Garner, R. 1967. Equations for determining the brine volume of sea ice from $-0.5^{\circ}$ to $-22.9^{\circ} \mathrm{C}$. Journal of Glaciology, Vol. 6, No. 48, p. 943-44.

Nakawo, M. 1983. Measurements on air porosity of sea ice. Annals of Glaciology, Vol. 4, p. $204-08$.

Nelson, K. H., and Thompson, T. G. 1954. Deposition of salts from sea water by frigid concentration. Journal of Marine Research, Vol.13, No. 2, p. 166-82.

Pounder, E. R. 1965. The physics of ice. Oxford, etc., Pergamon Press. (The Commonwealth and International Library. Geophysics Division.)

Ringer. W. E. 1928. Über die Veranderungen in der Zusammensetzung des Meereswassersalzes beim Ausfrieres. Conseil Permanent International pour l'Exploration de la Mer. Rapport 47, p. 226-32.

Schwarz, J., and Weeks, W. F. 1977. Engineering properties of sea ice. Journal of Glaciology, Vol. 19, No. 81. p. 499-531.

Schwerdtfeger, P. 1963. The thermal properties of sea ice. Journal of Glaciology, Vol. 4, No. 36, p. $789-807$.

Weeks. W. F., and Assur, A. 1967. The mechanical properties of sea ice. U.S. Cold Regions Research and Engineering Laboratory. Cold regions science and engineering. Hanover, N. H., Pt. II, Sect. C3.

Weeks, W. F., and Lofgren, G. 1967. The effective solute distribution coefficient during the freezing of $\mathrm{NaCl}$ solutions. (In Ōura, H., ed. Physics of snow and ice: international conference on low temperature science... 1966. ... Proceedings, Vol. 1, Pt. 1. [Sapporo], Institute of Low Temperature Science, Hokkaido University, p. 579-97.)

Zubov, N. N. 1945. L'dy Arktiki |Arctic ice|. Moscow, Izdatel'stvo Glavsevmorputi. 